\title{
Re: Intraurethral Injection of Autologous Minced Skeletal Muscle: A Simple Surgical Treatment for Stress Urinary Incontinence
}

\author{
Gräs S, Klarskov N, Lose G
}

Copenhagen University Hospital Herlev, Department of Obstetrics and Gynecology, Herlev, Denmark

J Urol 2014;192:850-855. doi: 10.1016/j.juro.2014.04.005. Epub 2014 Apr 13.

\section{EDITORIAL COMMENT}

In this study, the efficacy of intraurethral injection of autologous minced skeletal muscle for the treatment of stress urinary incontinence (SUI) was investigated. In the recent years, stem cells and treatment modalities using autologous cells have been popularized in the treatment of urinary incontinence. Although the initial studies in this field got into trouble because of ethical and legal problems and suspended for a while, encouraging results lead investigators to further investigations (1). In this study, the authors investigated the effects of autologous minced skeletal muscle cells that were injected intraurethrally just outside the urethral smooth muscle under ultrasonographic guidance in a total of 35 patients having uncomplicated and complicated SUI. After one year of follow-up, a clinical recovery or improvement was observed in 63\% of uncomplicated and 57\% of complicated patients. No major, but a few minor complications, such as infection, mild pain and hematoma were observed. In the previous issue of the same journal, a similar article by Peters et al. (2) demonstrated the efficacy of autologous muscle cells which was dose- (the number and weight of the muscle cells injected) dependent. As a conclusion, treatment modalities like autologous cells, stem cells and tissue engineering are increasingly used in many fields of medicine and it is encouraging that the efficacy of these has been shown and proven in urinary incontinence. Further studies comparing these methods with standard surgical treatments, injections and placebo are needed for autologous cells to take place in daily practice.

\section{REFERENCES}

1. Abbott A. Doctors accused of doing illegal stem-cell trials. Nature 2008;453:6-7.

2. Peters KM, Dmochowski RR, Carr LK, Robert M, Kaufman MR, Sirls LT, Herschorn S, Birch C, Kultgen PL, Chancellor MB. Autologous muscle derived cells for treatment of stress urinary incontinence in women. J Urol 2014;192:469-476.

Ali Ersin Zümrütbaş, MD 